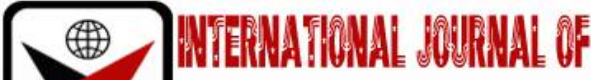

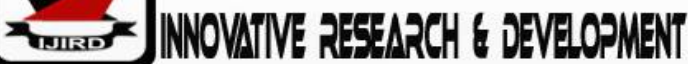

ISSN 2278 - 0211 (Online)

\section{Implementation of Economic Social and Cultural Rights under the African Charter on Human \& Peoples Rights}

\author{
Daniel Pelu-Jones \\ Lawyer, Department of Human Rights, Robinson O’Neill Solicitors, Dublin, Ireland
}

\begin{abstract}
:
The logic behind an affluent execution and imposition of Economic social and cultural rights are covered by the African Charter. As per Odinkalu, economic social and cultural rights must come under the African Charter on Human and Peoples' Rights. It should have the power to defeat three hurdles are pessimism, History and Ideology'.1

There are many challenges continuously arising regarding the issue of the rights in question as it is full of summons. Some critics are calling it full of ambitions only.

Moreover, there are many evidences that the economic social and cultural rightscannot be administered through legal ways.

However, cases like the SERAC case of the Ogoni people in Nigeria have countered this notion while noting that Economic social and cultural rights are indeed capable of imposing obligations of both a positive and negative nature on states and that adjudicative bodies could determine violations of these Rights.

This essay assesses to what extent mainly the prospects and challenges faced while doing applications. Practices and Procedures will be assessed and to what extent the Charter really affords adequate protection by ensuring enforcement of these Rights. lacunas in the law such as the claw back mechanisms will be discussed at and how these gaps could be bridged.

The essay also assesses the challenges faced by the institutional mechanisms in implementing and enforcing these rights. The essay will also examine the link between the main players in the African Human Rights system and how they interrelate.
\end{abstract}

Keywords: Political will, economic social and cultural rights, African charter on human and people's rights

\section{Introduction}

Economic, social and cultural Rights have suffered neglect right from the colonial times. These rights were viewed as a favour by the colonial masters rather than rights of the subjects.

Colonial policies in Africa then was more of an extractive economy where resources are simply taken to feed and develop the home territories of the colonial powers. These highly discriminatory policies ensured that Africa had minimal benefits from the resources of the continent ${ }^{1}$. Post Colonial Africa does not present a different story. Following in the legacies left by their masters African leaders had over the years dictated the pace of development for their peoples. Economic Social and cultural Rights was viewed as Rights of the Governor and a privilege of the governed, and the people were not given an opportunity to participate or influence the developmental process. ${ }^{2}$

Secondly, Post colonial Africa was more about a total liberation and emacipation of the continent from colonialism so much so that Economic Social and Culutral Rights were relegated to the Background. Rather there was a focus on the political conditions especially of the newly independent states. A case of 'seek ye first the kingdom political Rights and all other Rights shall be added unto you'.

Also because post colonial Africa was more about the liberation struggle and emacipation, the Charter of the Organisation for African Unity (OAU) was less vivacious about the welfare of the African people. ${ }^{3}$

The Charter's centre of attention was mainly on the accord and collaboration of the African Continent to grapple the common 'foe'. This focus was to change slightly in the next 10 years that followed with the independence of Namibia and the end of Apatheid in South Africa. ${ }^{4}$ African leaders have over the years championed and called for Human Rights, economic development and Regional cooperation, but over 3 decades on, there has been systematic failure to ensure the realisation of these goals and ideas. Three decades following independence, Africa is Plagued with poverty and economic growth is been thwarted, remaining a marginalized continent in international Politics.

1 J. Oloka-Onyango, Beyond the Rhetoric: Reinvigorating the Struggle for Economic and Social Rights in Africa, (Californian Western International Law Journal, Volume 26, 1995, No 1

2Ibid

${ }^{3}$ Ibid

4Ibid 
Africa's development must start within the continent, and there must be an ability and a capacity to enforce rights for the people.

Indeed access and freedom of using the socio economic rights must be viewed as vital to consolidatory Democratic reforms on the continent and curbing the consistent regime changes on the continent either by the power of the gun or the power of the people.

\section{The African Charter on Human and Peoples Rights}

The whole African system of protecting Human Rights is based on the African Charter on Human and Peoples' Rights. Following ratification, the Charter entered into force in 1986, and it was not until over a decade that the Organisation of Afrca Unity, following an adoption of the protocol of the African charter that an African Court on Human \& Peoples Right was established. This court was to serve as a complimentary enforcement mechanism to the African Commission on Human and Peoples' Rights.

However until the coming into force of the African Human rights court the African commission was the sole institution that was tasked with the implementation of the Right as contained in the charter.

The charter itself has been described as one that 'creates an ineffectual enforcement system. 5 Most notable is its ability to codified the idea of 'a peoples Rights' while imposing duties on individuals. ${ }^{6}$ However also notable is what have been described as the failures of the African system, the claw back clauses contained in the charter, an abuse of the language of duties and third the rather weak protection mandate given to the African Commission.The Charter is still applauded for significant contributions to the jurisprudence of African Human Rights.

No doubt recent times in Africa, with its current call for political reforms and the demand for economic and social reforms in my opinion offers an opportunity for the enforcement mechanisms to thrive in the present political dispensation.

In the present political dispensation, the enforcement mechanism are capable of operating in a rather more conducive atmosphere. This is because even the rather cynical environment that had greatly reduced the efficacy of the commission is gradually erroding away. There is a reviewed consciousness amongst the African People that there is hope. If there is anytime that mostly favours an empowerment of an effective Human Rights enforcement mechanism it is now. In assessing the procedure and practices of the enforcement mechanism.it will be necessary to look at the various institutional arrangements that exists under the charter. Is it a matter of a clear cut division of labour or of a complementary arrangement. But most importantly whatever these arrangement maybe in terms of the practice and procedure they should be those that are most effective in securing, implementing and enforcing the Rights in the charter. What synergy of relations must exist say between the courts and the commission. Should the courts be given the sole mandate of protecting, while the Afrcian commission be left to tackle promotional issues. ${ }^{7}$

The African Charter on Human and Peoples Rights is innovative one, as it has enabled many chances of Human Rights. ${ }^{8}$

With its 68 articles the charter sought to formulate the 3 generations Rights, ${ }^{9}$ while the provisions are capable of imposing duties on individuals. Thereby linking the concepts of Human Rights , the idea of a peoples Rights and imposing duties on Individuals.

However one of the most critcised flaws of the charter is the claw back clauses. These clauses have given significant range of discretion to member states and have allowed states to limit rights usually using domestic laws. This has a very negetive impact on Human Rights because what these claw back clauses do is allow African governments keep in their statute books very repressive and draconian domestic laws. ${ }^{10}$

Claw back clauses are essentially limitations or qualification phrases such as 'subject to law and order', 'within the law', 'except for reasons and conditions previously laid down by law', 'in acccordance with the provisions of the law', 'protection of nationalsecurity'.11 Usually repressive regimes rely on these clauses to totally do away with certain fundamental Rights in domestic laws. What this demonstrates is the leverage granted repressive regimes by the charter via these claw back clauses, to deny certain fundamental Rights. ${ }^{12}$

As a matter of opinion the charter must be revisited and rid of these 'claw back' clauses, while the idea of non-derogable rights can be introduced.

The Language and duties of the charter in its jurisprudence addresses two forms of duties. On the one hand the charter addresses the duties that individuals owe to one another, duties individuals owe to their communities and to the state as a whole. Then on the other hand the duty a state owes to individual.13

Critics of the language of Duties of the charter have often described the duties as nothing but 'little more than the formulation, entrenchment and legitimation of state Rights and privileges against individuals and peoples'.14 The

\footnotetext{
5 Makau Mutua, The African Human System; A critical Evaluation

6Ibid

7Ibid

8Ibid

${ }^{9}$ The Three Generation Rights

10 Ibid

${ }^{11}$ See Provisions of the African Charter

12 Arthur E. Anthony, 'Beyond the Paper Tiger: The Challenges of a Human Rights Court in Africa'32 International Law Journal 511, 518 (1997)

13 African Charter on Human and Peoples' Rights, Article 27(1) \& 28

${ }^{14}$ H.W.O Okoth- Ogendo, Human and People's Rights: What point is Africa Trying to make in Human Rights and Governance, at pp74, 78-79
} 
arguement had been around the idea of the concept of Duty and individual rights, which some believe may be highjacked by the states if too much emphasis is laid on duties whenever the two concept of duties and rights conflicts. ${ }^{15}$

Critics of the charter have raised concerns over how some specific provisions in the charter were drafted and had questioned the commitment of the African Union to its realization.

Article 10 for instance provide for freedom of expression but also notes that the Rights are only exercisable provided the individual 'abides by the law'. Member states have capitalised on this article and banned the formation of trade Unions. Also Article 29 which relates to preserving and strenghtening of national solidarity is usually been interpreted to mean 'oppositional activity' be it economical or poitical.

Article 15 relates to the riights to work and equal pay, but the fact that because the continent battles with poverty and underdevelopment, and most are self employed, this therefore places limitations or restrictions on the realization of this right.

Article 16 mentions the rights to enjoy best attainable state of physical and mental Health, while Article 17 notes the Rights to education, but does not mention free education at any level. This places a limitatin on Article 17, taking into congnisance the fact that due to poverty and underdevelopment issues in Africa many cannot afford education. The guarantee of free education in the charter at least at the primary level will give some progressive meaning to Article 17. Quite conspiciously missing are Rights such as the 'right to adequate standard of living', 'freedom from Hunger', and the 'rights to food', given the obvious that the most demanding issues of a majority of Africans are the provision for their basic needs, such as Food and Shelter.

If these basic rights are provided for and guaranteed in the charter, then maybe state politicians could be held accountable for plundering their citizens.

\section{The African Commission}

The African commission is mostly vested with the duty of promoting the African charter on peoples' and Human rights. Though it also functions as a protective mechanism, there seem to be a high level of ambiguity regarding its protective function.

A year following the entering into force of the African charter, the African commission was established. ${ }^{16}$ It basic function includes the dessimination of information about the charter and the African Human Rights system. This it does through organising workshops and other informational sessions. While interacting with other international Human Rights organisation. ${ }^{17}$ It also plays some sort of an advisory role when called upon to interpret some ambigious areas of the charter. This, it does at the request of the member states. With regards to its protective mandate the charter note, that it shall 'ensure the protection of Human and peoples rights in the charter'.18 Other specified functions will include the examining of state Reports and assessing communications that alleges violations. ${ }^{19}$ It is worth noting at this juncture that the African commission seem to draw a lot of its procedure from the United Nations Declaration of Human Rights, notably the procedure of the United nations Human Rights Committee. ${ }^{20}$

Article 47 and $55^{21}$ stipulate various forms of communications. Communications may involve those from non governmental organisations, individuals other groups and states.

As to who may bring a case before the commission no restrictions are placed here. However before the committee considers any communication, the person authoring the communication must not be anonymous, and must ensure that the communication is not written in a manner that insults the state in question, or the African Union, and that the petitioner has exhausted all local remedies unless there are no adequate local Remedies. ${ }^{22}$ This is quite similar to the United Nations Human Rights Committee's procedure for considering individual communications.

Critics and commentators have argued that usually the overall decision of the commission lacks substance and reasoning, right from when the facts are assessed, arguement made to issues of adimissibilty and eventually its findings. ${ }^{23}$ This is evident in two cases, the constitutional Rights Project $v$ Nigeria, and the Civil liberties organisation v Nigeria case. Further more the commission's main objective is to serve as a conduit of dialogue between the disputing parties, which is aimed at achieving some amicable settlement. ${ }^{24}$

Many share the opinion that the absence of an enforceable mechanism or some remedies in the African charter and the commission makes it rather impossible for the commission to follow on its decision and ensure some compliance by member states. ${ }^{25}$

Another problem plaguing the commission is the lack of resources notably financial resources. A commentator noted that 'the resources and personnel problems of the commission as endermic... ${ }^{26}$, describing it as 'opaque and difficult to interpret'.

\footnotetext{
${ }^{15}$ Ronald Cohen, Endless Teardrops: Prolegemania to the Study of Human Rights in Africa, Human and Governance, at p 15

${ }^{16}$ African Charter, See more on the establishment of the African Commission, Articles 30, 33, 31 (2), 36 \& 39 (2)

${ }^{17}$ Ibid Article 45(1)

${ }^{18}$ Article 62 'State must submit every two years a report on the legislative and other measures taken to give effect to Rights in the African Charter

${ }^{19}$ Op cit Makau note 6

20 United Nations General Assembly Resolution 220

${ }^{21}$ African Charter, Article $47 \& 55$

22 op cit, Makau Wa Matua, note 6

23Ibid Matua Makau

${ }^{24}$ Ibid

25 Ibid

${ }^{26}$ Chidi Anselm Odinkalu, The Individual Complaint Procedure of the African Commission on Human \&People's Rights: A preliminary Assessment. 8 Transitional law \& contemporary Problem 359 (1998) 365, In Steiner, Alston \& Goodman - International Human Rights in Context, Law Politics \& Morals
} 
Usually the commission objective in addressing individual compliants is to seek some form of a dialogue between the complaint and the state concerned, which is geared towards reaching an amicable resolution of settlement of the disputes. ${ }^{27}$ Achieving this the commission had stated that, this will depend on what it called good faith and the willingness to dialogue. Hence in the 1996 case involving the Free legal Aid Assistance Group case, the commissioner noted that the main aim of the commission is to seek a settlement. In arriving at this, the commission noted that the subjectives and objective test must be met by the parties, ${ }^{28}$ and that subjectively parties must accept the results and objectively they must act in good faith. ${ }^{29}$

The African Commission in recent times have been criticised for attempting to favour some sort of amicable settlement that favours state parties. This demonstrates the commission's willingness to follow through on these settlement without providing any guidelines for compliance and verification. ${ }^{30}$ This procedure can only dent the image of the commission and its credibilty may be questioned.

\section{The African Human Rights Court}

The idea of estblishing an African Human Rights Court was to establish an institution that will correct some of the defects of the whole African Human Rights system. An institution that will render some efficacy to the enforcement and implementation of Economic, Social and cultural Rights. ${ }^{31}$

There are two divergent views on the need for an African Human Rights Courts. The first view sees the need for an institution that will be robust enough to add some bite to the whole Human Rights enforcement in Africa. In the opnion of the proponents of this position a court of competent jurisdiction can correct some of the flaws of the present system. ${ }^{32}$ On the other end of the spectrum is the view that the workings of the commission is a gradual and evolving process which must be seen more in the light of promoting the system rather than a strict Adjudicative role. Proponents of this thought are of the opinion that the public must first be educated through its promotional functions.

\section{The Jurisprudential Limitation to the Execution of Economic Social and Cultural Rights in Africa}

From the very beginning the African commission is dealing with Economic Social and cultural rights. All of these cases that were dealt with by the commission demonstrates the commission's zeal or enthusiasm or commitment to the promotion and protection of human Rights on the continent. Quite worrisome is the fact that despite the numerous violations found by the commission, its jurisprudence has not been very clear on either the legal position of rights violated. ${ }^{33}$ This results is a situation where adequate remedies are either not enough or simply absent. In the light of these developments there is need to assess the aftermath of violations found and the efforts or attempts made by the commission to ensure that these violations are remedied. For instance in the Joshua Modise case, ${ }^{34}$ the compliment was denied citizenship by Botswana and South Africa and as a result was rendered homeless. The commission in upholding Article 8 of the Charter ruled that there was a violation of Article 5 that his state of homelessness is deemed an inhumane and degrading treatment. In the Union Interafricaine des Droits de l' Homme $v$ Zaire ${ }^{35}$, the commission held a contravention of Article 16 of the Charter. In this case a magistrate was not reinstated to his position following a suspension, when others equally accused of the same offence where reinstated. No doubt one of the biggest shortcomings of the commission on Human and Peoples Rights regarding its protective mandate is its inability to implement and enforce decisions or recommendations on the member states. This frustration has been of great concern to victims or complainants of human Rights abuses. Moreso this brings the jurisdictional competence of the commission to question. In the Civil liberties organisation case ${ }^{36}$, the mandate and jurisdiction of the commission was seriously questioned thereby challenging the commission's ability to issue recommendations. In doing this the Nigerian government suspended the applicability of the charter. Even though the commission held a violation of its obligation under the African Charter, the then military junta ignored this.

The absence of a followup mechanism hampers enforcement and implementation. A viable and logical followup mechanism to monitor implementation or enforcement must be provided for, this is crucial to the success or failure of the whole system. ${ }^{37}$ Also related to enforcement and implementation is the issue of delay of cases, where the rather indifferent attitudes of states parties request that cases be adjourned. This really hampers the flow of the commission. Most relevant is the Endorous case where the Kenyan government was indifferent to the applicants complains, and was only prompted to act when the admissibility of the case was ruled on.

Concerns have also been raised regarding the recent growth of some regional courts on the continent and whether these courts conflict in terms of jurisdiction with these other regional courts. The court of justice of the Econnomic community of West African states (ECOWAS), the East Afrian court of justice and the Tribunal of the Southern African Development community (SADC). ${ }^{38}$ Jurisdictional conflicts and overlapping of jurisdictions have occurred between these

\footnotetext{
27 Ibid Steiner

${ }^{28}$ Ibid Steiner

${ }^{29}$ Ibid Steiner

${ }^{30}$ Ibid Steiner

31 op cit Matua Makau

32 Ibid Makau note 33

${ }^{33}$ Kabanye Nkongolo Christian-Junior, 'Protection of Human Rights in Africa: African Human Rights in a Comparative perspective'

${ }^{34}$ Modise case

${ }^{35}$ Union Interafricaine des Droits de l'Homme v Zaire

36 Civil Liberties Organisation v Nigeria

${ }^{37}$ George Mukundi Wachira, African Court on Human and People's Rights: Ten Years on and Still no Justice (Minority Right Group International 2008) 38 Ibid
} 
courts and the African Court on Human and Peoples Rights. For a more efficient Human Rights protection these jurisdictional overlapps must be resolved. While these regional court have vested jurisdictional powers to make pronouncements on key Human rights violations the charter is rather silent on this conflict of jurisdiction, and has left room for discretional exercise of jusrisdicitonal powers which may be based on superiority to determine how to resolve such overlapps that may occurr form time to time..$^{39}$ Where a matter comes before the African courts and the Regional courts commentators have suggested that the Regional court be viewed as an international Tribunal. In this way matters already before the regional courts cannot be adjudicated on by the African Court on Human and Peoples Rights. Some coherent interpretations are there to give much credence to the charter and strenghten the jurisprudence of African Human Right Law. ${ }^{40}$ No doubt with better coordination between these courts' problems such as 'forum shopping' could be avoided. Chidi Odinkalu a prominent commentator on African Human Rights once noted that cooperation between the various regional courts will not only prevent 'forum shopping', but will minimise contradicting jurisprudence on the charter. ${ }^{41}$

\section{Implementing or Enforcing the Rights}

The African commission in its attempts to operate or implement Economic social and cultural rights is been mandated by Article 40.42

Major parties to the charter have approved the International covenant on economic social and cultural rights. ${ }^{43}$ However there exists basic dissimilarities related to functions between the international covenant. ${ }^{44}$ From the number of states that have ratified the covenant it is deduced that most of the African state parties to the charter will prefer the 'progressive realization standard as compared to the more obligatory requirement standard of the African charter. ${ }^{45}$ Arguably the ratification of the covenant does not necessarily improve the standard of perception on how these African states view or understand these obligations. Indeed a significant number of the African states constitutions recognise that economic, social and cultural rights are enforceable rights. ${ }^{46}$ Therefore Odinkalu summed it up when he noted that it would be counter productive for the commission to interpret the charter so as to minimise obligations that the state parties themselves undertake in their own basic law.' 47

With regards to the enforcement of the African commission's recommendations Article 59 of the charter only requires that the commission reports be submitted to the African Union Assembly, but does not place an obligation on the African Union to act. Furthermore the chamber noted that the commission could make recommendations to the African Union Assembly under Article 53 and 55 which relates to cases of serious Human Rights violations. Though it does not place an obligation on the Assembly to take an action it could be inferred that the African Union had some perogative to determine ways of enforcing these rights. ${ }^{48}$

Article 9 (1) (b) of the constitutive Act provides that the Assembly 'shall receive. Consider and take decisions on the recomendation from other organs of the union'. 49

Generally a close look at Article 45 (1)c and 59(2) of the charter , Rule 72 of the Rule of procedure of the African commission and Article 3 (b) of the constitutive Act could be implied as meaning that the African Union remains the most supreme body responsible for ensuring that recommendations are complied with. It is important to note that the African Union remains a pivotal regional organisation through which the shame and 'peer pressure' methods could be used to force states to fulfill their obligations under the African charter. ${ }^{50}$ Following the suggestions of the African commission by the African Union Assembly, it has become important for African Union to act as per with the Article 9 (1)b of the constitutive Act ${ }^{51}$ which states clearly the duties of recieving, considering and taking decisions on reports and recomendations from other branches of the union. Furthermore the Rules of procedure of the African Union explains how the decision should be implemented. ${ }^{2}$ 'decisions shall be issued through regulations that will apply in member states and all the steps shall be taken to implement them'.53 Any directive which will be directed to all the member states will be binding on states to the objective to be achieved but will leave some margin of appreciation to the state to determine the form it will take and how it will be implemented. ${ }^{54}$ Recommendations declaration and resolutions on the otherhand are not binding, but it is intended that it guides the view point of member states. Article 23(2) note that 'non implementation of regulations and directives shall attract appropriate sanctions inaccordance with Article 23 of the constitutive Act'. 55

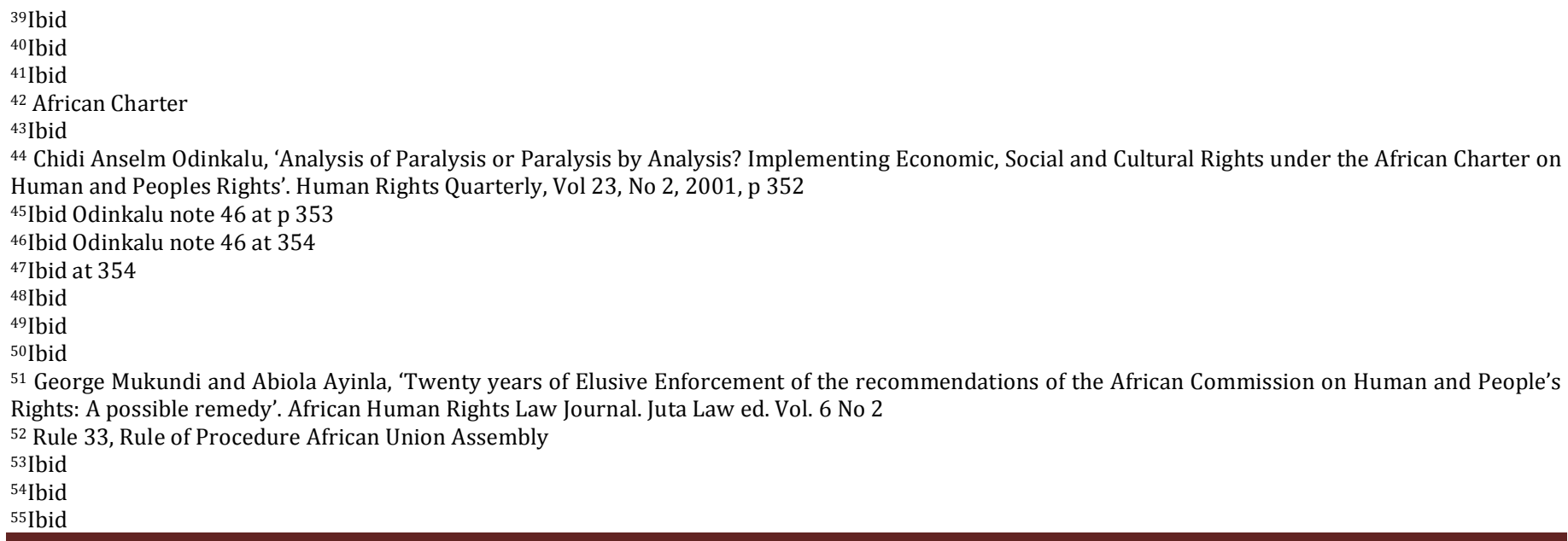


Rule 34 further provides more insights into the implementation of Regulations and directives. It notes that 'regulations and directives are automatically enforcable 30 days after the date of the publication of the official journal of the African Union, or as specified in the decisions'. ${ }^{6}$ So far all the communications or recommendations that have been presented by the commission and adopted by the African Union Assembly falls under recommendations ${ }^{57}$, because during its adoption it was not classified under directives or regulations. Also these recommendations are not published in the official journal of the African union but rather adopted as activity report of the commission. What this simply means is that, because it does not fall under any of the binding decision making processes it will not be considered as legally binding. ${ }^{58}$ Notwithstanding the current standing of the commission's recommendations Article 45 (1) c of the charter requires that the commission cooperations with other international institutions while also emphasizes a relationship of cooperations with the organs of the African Union. ${ }^{59}$

The African commission's rules of procedure provides that the African Union Assembly remains the ultimate body that has the primary political responsibility to ensure or otherwise monitor that the recommendations are being complied with. ${ }^{60}$ Also under the African charter the African commission's lack of enforcement powers coupled with the non binding nature of its recommendations or opinions brings to the fore a vital challenge that may impede implementation of economic social and cultural rights. Unfortunately the recommendations of the commission somehow stands at the mercy of member states. ${ }^{61}$

It is also true that where the decision of an international organisation like the African commission is binding, this is not enough to ensure that states comply. In most cases an effective enforcement mechanism is needed to ensure compliance.

An inspection towards the activities of the African Union Assembly highlighted that the African Union placed with authority to check and validate the regulations, directives. ${ }^{62}$ The African Union Assembly will arguably be the best platform that could provide some sort of a political framework, ${ }^{63}$ to ensure that the recommendations of the commission are implemented.

The role of the African Union Assembly in the implementation of Economic, social and cultural rights cannot be under estimated just as Mukundi and Ayinla noted in their review, that 'the African union structure latently provides a political framework for the enforcement of the recommendation of the African commission'.64

Other commentators had mentioned the African Union as a channel through which peer pressure could be channelled, ${ }^{65}$ sugggesting the idea of involving a shame and peer presure approach on recalcitrant states. ${ }^{66}$ Furthermore the union could impose stiffer sanctions on States in accordane with Article 23 (2) of the constitutive Act which empowers the union to carry out sanctions against states that do not comply with decisions of the Union. ${ }^{67}$

Article 23(2) of the constitutive Act could be given a Human Rights interpretation that will cover its application not only to recommendations but can be extended to cover regulations and directives of the union. ${ }^{68}$ Notwithstanding that Rule $33(2)^{69}$ forbids that the interpretation of Article 23 (2) be made to cover regulations and directives, ${ }^{70}$ article $23(2)$ of the constitutive Act surely overides Rule 33(2) because it makes a general reference to the decisions and policies ${ }^{71}$ of the Union.

The recommendations of the African commission could be given some binding effect by ensuring that it is adopted as directives. This could be done by ensuring that the decisions of the Assembly based on the recommendations of the commission are termed directives, thereby bringing them within the perimeters of Rule 33(2) which will then clear any doubt as to whether not complying could trigger sanctions. ${ }^{72}$

In comparison to the European system Article 8 of the statute of the council of Europe ${ }^{73}$ vest powers in the committee of ministers to sanction states that do not comply with decisions. Also the idea of explusion as a form of sanctions can be considered as an effective enforcement mechanism. The African union could provide a viable platform for the enforcement of Rights, especially economic social and cultural Rights on the continent. But before this could be achieved, there is need for a rejuvenating or as a commentator put it 'an activation by the commission and other existing Human Rights Insitutions', ${ }^{74}$

A former chairman of the commission highlighted that this commission paying attention mainly on Civil and Political Rights. This explained why from the inception of the commission up to 1995, of the 140 communications received via the complaint mechanism none of these concerned Articles 14-17 which relates to Economic Social and cultural Rights.

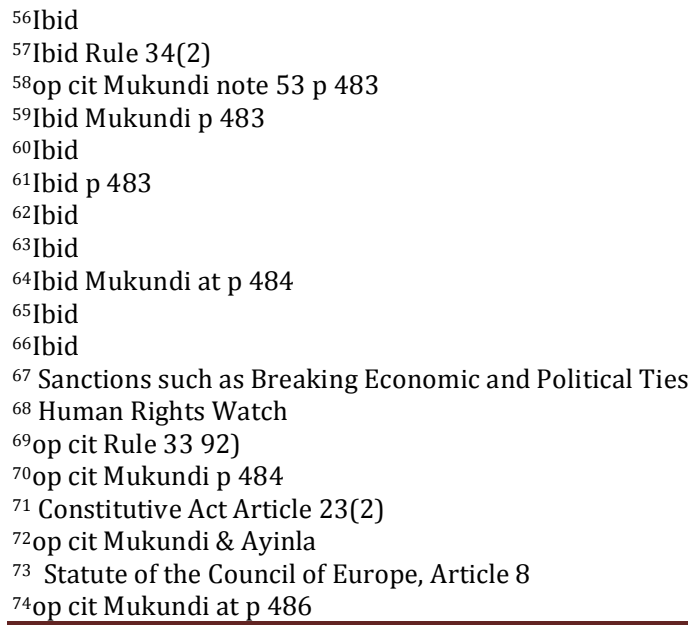


Economic, social and cultural rights have often been compared with Civil and Politcal Rights, while the two have often been described as either indivisible or interdependent on each other. ${ }^{75}$ For instance the government has to provide a safe working environment making sure that education could be assessed by all interested, and this triggers some sort of a positive obligation on states. ${ }^{7}$

Then comes the issue of justiciability of Economic Social and Cultural rights. ${ }^{77}$ Therefore if one takes the view that these Rights are justiciable what then follows after a case has been adjudicated on and ruled in favour of an individual. In this case, if following adjudication of a case no compensation is given in the case of an individual or in the case of a state the recommendation is flouted with impunity then it follows that the rights guaranteed has not been exercised. Indeed the essence of adjudication is redress or compensation. Turning on the question of implementability of economic social and cultural rights, the progressive view ${ }^{78}$ of implementation have been argued as against the justiciability approach or view. This author is of the opinion that indeed economic, social and cultural rights are justiciable and therefore implementable. ${ }^{79}$ However implementation must be viewed progressively, because where a state had been found to be in violation of its obligations to implement rights say of an economic nature issues such as underdevelopment could prevent a complainant from achieving relief immediately. 80

But does implementation of a Right necessarily mean a right has been guaranteed or secured. ${ }^{81}$ At what point can a right be described as being implemented, is it at the implementation stage or at the adjudication stage or at the stage when a relief is granted or compensation given. ${ }^{82}$ Then suppose a court or quai-judicial body rules in favour of an individual, but the state do not compensate the individual, could it be aruged that a right has been implemented. ${ }^{83}$ These in this authors opinion are the fundamental questions that borders around the issue of implementation of economic social and cultural rights, especially in Africa.

Under other Human Rights systems, limitations or derogations are provided for and these prescribe under what circumstances that one may derogate from a right. ${ }^{84}$ Under the African charter there are no derogations clauses but rather claw back clauses. This is simply the taking away of a right given through on entrance and the taking back again via another exit. Article 14 for instance guarantees a Rights to Property however another provision notes that it may be encroched upon in 'accordance withthe provisions of appropriate law'. Article 12, concerning freedom of movement , provides that an individual 'abides by the law'. Article 10 though guaranteed freedom of association, this could only be done provided and individual 'abides by the law'. Artile 9 provides that freedom of expression is guaranteed provided it is done'within the law'.

Freedom of conscience and religion are guaranteed under Article 8 again 'subject to law and order'.

Claw back clauses as is seen could be as a commentator noted 'render previously granted rights meaningless'.

This author suggests that the African commission in dealing with complaints should first concern itself with whether certain domestic laws limits rights and if indeed its found that domestic laws prohibits the exercise of Rights, these provision be ruled as been in violation of the African charter, indeed the African commission had undertaken such challenges in the past and held a violation of such legislations as inconsistent with the charter.

\section{The Holistic Approach (Concerted And Integrated) to Solving the Problem}

There exist a fundamental difference between poverty or deprivation and conflict in the Protection of Human Rights, and there exists a relationship between Human Rights \& Stability, and this butresses the point that enforcement of human Rights must be Holistic in nature and that Human Rights must be a gurantee for all without any exceptions. ${ }^{85}$ Therefore it follows that to achieve the implementationof a set of rights it is very dependent on the realization of another right. For instance in a State where there exist conflict because of deprivation and the absence of Economic Social and Cultural Rights, Civil and Political Rights, application will be almost difficult ${ }^{86}$

Also the non enforcement of Economic Social and Culutral Rights creates problems to the total achievement of Civil and Political Rights,.87 For instance abject poverty and illiteracy is at the core of the total lack of empowerment for many Africans to assert their Rights. ${ }^{88}$ To many rural dwellers in any African States and indeed to the Urban poor, the Lack of awareness makeit impossible for them to assert their Rights. They are very much at the mercy of their rulers' ${ }^{89}$

\footnotetext{
75 Evelyn Ankumah: 'the African commission on Human and People’s Rights: Practice and Procedure' (the Hague Maritinus Nijhoff 1996) at p 143

${ }^{76}$ Ibid Ankumah at p143

${ }^{77}$ Ibid at p144

${ }^{78}$ Ibid at p144

${ }^{79}$ Ibid at $\mathrm{p} 144$

${ }^{80}$ Ibid at $\mathrm{p} 144$

${ }^{81}$ op cit Oloka-Onyango note 2

${ }^{82}$ Ibid

${ }^{83} \mathrm{Ibid}$

${ }^{84} \mathrm{Op}$ cit Ankumah at p 176

85 Shadrach Agbaka 'Reclaiming Humanity: Economic Social and Cultural Rights as the corner stone of African Human Rights' 2000 Yale Human Rights \&

Development Law Journal

86 Ibid

87 Ibid

88 Ibid

${ }^{89}$ Umozurike U. O The African Charter on Human and People’s Rights,' The Raoul Wallenberg Institute Human Rights Library Volume 2 (Martinus Nijhoff \& Kluwer Law International 1997)
} 
Practically, any State should pay equal attention on civil and political Rights as well as Economic Social and Cultural Rights.90There is a total liberation of the continent in terms of the implementation of Economic social and cultural rights. 91

The interconnectedness, interlinked and indivisibility of all forms of Human Rights is factually true.92 Hence the famous quote, 'one man, one vote is meaningless unless accompanied by the principle of one man one bread'. 93

In discussing the relationship between civil and political right and Economic social and cultural rights, Rhoda Howard noted that the debate borders around which set of rights are more important. ${ }^{4}$ Whether these sets of Rights contained in the famous covenants, ${ }^{95}$ can be described as interrelated and therefore developed simultaneously or otherwise the two types of rights must be prioritized. ${ }^{96}$ No doubt African states have realized the need and importance of a Holistic approach to the implementation of Rights rather than a selective approach. The African Charter on Human Rights is testimony to this, in that the African Charter is worded in a way to reflect the need for a Holistic approach to the implementation of Rights. ${ }^{97}$

Therefore a holistic enforcement of Rights will ensure that Economic Social and Cultural Rights are achieved which will in turn guarantee Civil and Political Rights. Economic Social and Cultural rights is the Key to any African nations Political stability.

Judicial enforcement of Economic social and cultural right in the continent has not been an easy task. challenges include the aspirational nature of the rights as largely shared by many states, and the non justiciablility notion still contained in the constitutions of many African States. The concerted approach can be adopted where Economic Social and cultural rights could be enforced through the provision of civil and political rights. ${ }^{98}$ The concerted and integrated approach is close to the functional and interpretative approach adopted by the european union. For example in the Airey $v$ Ireland case, ${ }^{99}$ where the court observed that 'while the European conventionon Human Rights set forth what are eventually civil and political Rights, many of them have implications of a social or economic nature.There is no water-tight division separating that sphere from the field of the convention'.

It is therefore possible that Economic, Social and Cultural Rights could be enforced or seen through the 'eye' of civil and political Rights. Therefore Domestic courts, Human Rights commission/institution, the African commission could enforce Economic Social and cultural Rights through Civil and Politcal Rights.

\section{Impediments/Obstacles to Realizing Economic Social and Cultural Rights}

The obstacles that have prevented Africa from totally realizing its potential in its quest to enforce Economic, social and cultural rights on the continent can be classified into two categories, 'the internal factors and external factors. ${ }^{100}$ The internal factors will include the normative flaws inherent in the African Charter especially provisions relating to Economic Social and Cultural Rights. The claw back clause and the rather ambigious construction of the provisions of the charter. For instance the provisions on Health, gives out a wide range of discretion to member states to construe the meaning and scope of the Right to Health. ${ }^{101}$ The provision notes an entitlement to 'best attainable state of physical and mental Health', but fails to define the scope of what the 'best attainable state' will mean. This may allow a member state to totally avoid this obligation with an excuse that it is too vague to interprete, hence implementation is not realizable.

The African commission has been criticised by many for its forcus mainly on Civil and Political Rights. Indeed one could argue that the African Commission cannot adjudicate on cases not brought before it, however Article 45 mandates the commission to undertake studies and conduct research on the continent that will lead to a sensitization and awareness that could encourage many to come forward to seek redress. 'the dearth of cases on Economic social and cultural rights is due in part to the commission's inadequate efforts to encourage such cases and to educate and sensitize people as to their rights'.102Makau Mutua is quoted as saying that the commission's decision and pronouncements are 'formulaic' and 'do not reference jurisprudence from national and international tribunals nor do they fire the imagination'.103

That corruption in Africa is the bane of its underdevelopment and the key element impeding the continent's development will fall nothing short of the truth.

African leaders have consistently exploited their people. While resource meant for the state have been diverted and put away in foreign accounts. Some indirectly have introduced developmental policies that will promote Economic social and cultural rights, that will provide them with personal gains and personal investment opportunities. ${ }^{104}$ Furthernore colonialism no doubt did its best to leave Africa totally battered and 'sapped' dry in economic and social terms.

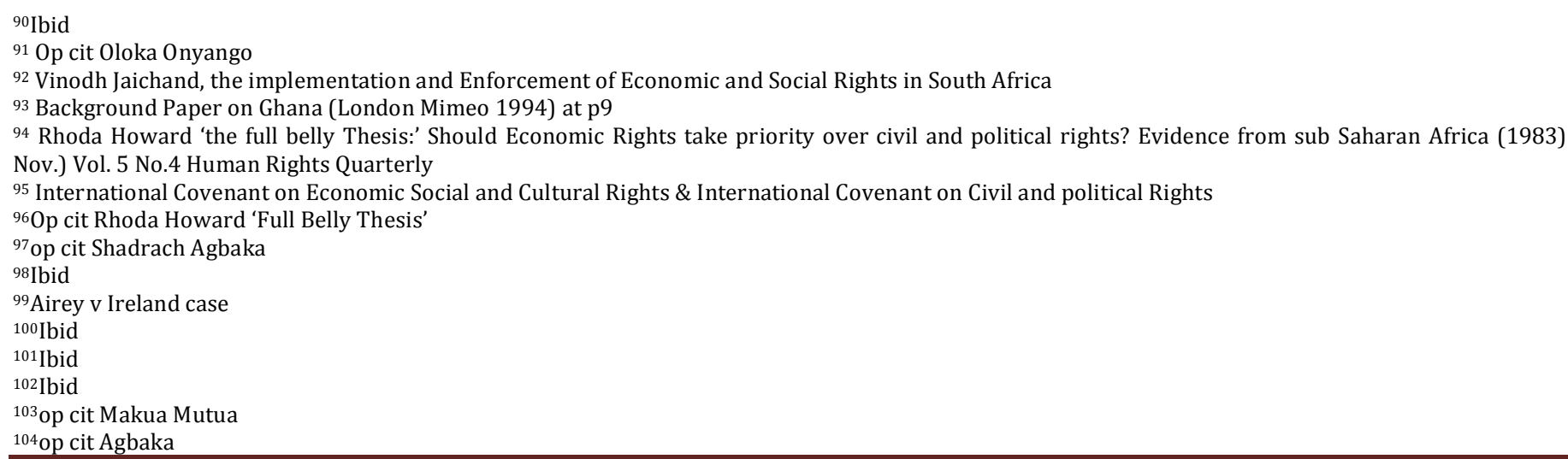




\section{Conclusion}

From this discourse it is quite clear that the journey so far to the implementation and realization of Economic Social and Cultural Rights has been full of 'Bumps and Pot holes', but there is still hope for a better and smoother ride to achieving this feat.

The role of Non governmental organisations in the implementation of these rights cannot be underestimated. However there should be no room for complecency in improving the effectiveness of the African Commission and indeed the African Court. Non governmental organisations should be more focused on constructive criticisms of the commission focusing onthe obstacles hampering the progress of the commission. ${ }^{105}$ Commentators have suggested a chairman who will be hired on a fulltime basis who will be engaged on a regular basis with states to ensure implementation. The obstacles of the commission are abound, such as the total lack of Political will on the part of member State governments, who flout the recommendations or directives of the commission by totally disregarding their obligation under the African Charter. Failure to comply with decisions of the commission, should be the focus of critiques by stakeholders in the quest for Africa's Human Rights developments. ${ }^{106}$ The disinclination from the African Union is basically to strengthen that the member States are responsible for contravention. Needless to say,that Economic Social and cultural rights come under Human Rights, 107 and for any implementation of these be made a Priority in African Human Rights Jurisprudence, and this will make a difference. The would be beneficiaries should be made aware of the existence of these Rights, for without the awareness that a right exist, effecting such rights will be a 'herculean task'. ${ }^{108}$

The failure on the part of the commission to adopt very clear guidelines for the conducting of investigations has been of concern to non governmental organisations. Non governmental organisations have highlighted the lack of serious preparation and delays in report which seriously impedes and undermines the whole investigative procedure. ${ }^{109}$

Furthermore the role of the state and the various national courts in the implementation of Economic Social and cultural rights must be understood in a way that rights and freedoms will be better guaranteed if the African Charter, is made part of domestic or municipal law. ${ }^{110}$

Article 25 states, 'state parties to the present Charter shall have the duty to promote and ensure through teaching education and publication, the respect of the rights and freedoms contained in the present Charter and to see to it that these freedoms and rights as well as corresponding obligations and duties are understood'.

Indeed some judges have relied on the provisions of the African Charter in domestic cases. Hence in the Ghana case involving New patriotic Party $v$ Inspector General ofPolice case, the court in its judgment by Archer CJ, relying on the African Charter held as unconstitutional a legislation which made a police permit a reqiurement for demonstrations. The Right to assembly is guaranteed by Article 12 and not even the restrictions placed on it could stopthe Supreme Court.

Archer CJ stated, 'Ghana is a signatory to this African Charter and member states of the Organisation of African Unity and parties to the charter are expected to recognise the rights, duties and freedoms enshrined in the charter and to undertake to adopt legislative or other measure to give effect to the Rights and duties".111 This was the approach and reasoning of the court.

Furthermore Member states must be encouraged to entrench Economic social and cultural rights into their constitutions. In South Africa for instance Economic social and cultural rights are entrenched in the nation's constitution, through the Bill of Rights which protects all rights. ${ }^{112}$ The SouthAfrican consitutional court considered Economic Social and Cultural Rights in the Soobramoney v Minister of Health, Kwa Zulu- Natal 1998 (1) SA 765 (CC), Government of the Republic of South Africa v Grootboom, 2001 SA 46 and the Minister of Health v Treatment Action Campaign 2002 (1) SA 721 (CC). ${ }^{113}$

There have many evidencesthat these Rights are justifiable under the African Charter. In the SERAC case,114 the legal bodies were there to check the deviations from these rights.

The western model is commited to the fullfilment of Civil and Political rights, because of the success of the west in attaining an appreciable standard of living, this invariably gives room for a better enjoyment of Civil and Political Rights.115 The African problem demands an African solution to solving the problem. The commitment may not be a total or maximum protection of Economic Social and cultural rights but at least an effort that will ensure some appreciable level of protection for the individual which will be practically achievable as demanded by the African Charter and the African people.

\footnotetext{
${ }^{105}$ Ahmed Motala, 'Non-governmental organization in the African system' at p 271

106Ibid, Ahmed at 271

${ }^{107}$ Opcit Evelyn Ankumah at p183

108Ibid Evelyn Ankumah at p 183

${ }^{109}$ op cit Ahmed Motala at p 263

110 Victor Dankwa 'The Promotional Role of the African Commission on Human \& Peoples Rights'.

${ }^{111}$ Some national courts have expressed their willingness to rely on the Charter. More in F. Viljeon 'Application of the African Charter on Human and Peoples' Rights by Domestic courts in Africa: Journal of Africa Law (1999)

112 Vinodh Jaichand, 'The implementation and Enforcement of Economic and Social Rights in South Africa' (Dublin 1006)

113 The Constitutional Court set the jurisprudence of Economic Social and Cultural Rights in terms of 'Reasonableness'

${ }^{114}$ Social and Economic Rights Action Center (SERAC) v Government of Nigeria

115 Ibid
}

INTERNATIONAL JOURNAL OF INNOVATIVE RESEARCH \& DEVELOPMENT 


\section{References}

i. Odinkalu, Anselm Chidi. Analysis of Paralysis or Paralysis by Analysis? Implementing Economic, Social and Cultural Rights under the African Charter on Human and Peoples' Rights. Human Rights Quarterly, Vol 23, No 2, 2001, pp 327-369.

ii. Nakuta, John. The Justiciability of Social, Economic and Cultural Rights in Namibia and the Role of the Non Governmental Organisations. Berlin: Konrad-Adenauer-Stiftung

iii. Juma, Dan. Access to the African Court on Human and Peoples' Rights: Acase of the poacher turned Gamekeeper. Essex Human Rights Review, Vol. 4, No 2, 2007

iv. Mbazira, Christopher. The Right to Health and the nature of socio-economic rights obligations under the African Charter: the Purohit case. Economic Self-Reliance Centre Review, Vol 6 No.4 2005

v. Chirwa, Danwood. Towards Revitalizing Economic, Social and Cultural Rights in Africa: Social and Economic Rights Action Center and the Center for Economic and Social Rights v. Nigeria. Human Rights Brief, Vol.10 No. 1 2002

vi. Jaichand Vinodh. The implementation and enforcement of economic and Social Rights in South Africa.

vii. Mukndi, George/ Ayinla, Abiola. Twenty years of Elusive enforcement of the recommendations of the African Commission on Human and Peoples' Rights: A possible remedy. African Human Rights Law Journal. Juta Law Ed. Vol. 6 No2, 2006, pp 465-492

viii. Henry Steiner, Philip Alston \& Ryan Goodman. International Human Rights in Context: Law, Politics, Morals, 3rd Edition, Oxford: Clarendon Press, 2008.

ix. Vincent O’Nimehille, Thte African Human Rights System; its laws, Practice and Institutions, Maartinus Nijhoff (2000)

x. Issa G. Shivii, The Concept of Human Rights in Africa (London: Codersic 1989)

xi. Rhoda Howard. ' The fukk-Belly Thesis: should Economic Rights Take Priority over Civil and Political Rights? Evidence from sub-saharan Africa (1983 Nov.) Vol.5 No.4 Human Rights Quarterly, 467-490.

xii. Evelyn Ankumah: the African Commission on Human and Peoples' Rights: Practice and Procedure (the Hague Maritinus Nijhoff-1996)

xiii. Shadrack Agbaka 'Reclaiming Humanity: Economic Social and Cultural Rights as the Corner stone of African Human Rights (2000) Yale Human Rights \& Development Law Journal, p177.

xiv. Courts and the legal Enforcement of Economic, Social and Cultural Rights- Comparative Experiences of Justiciabilty. Human Rights and Rules of Law Series: No 2 (International Commission of Jurists)

xv. Van der Linde, Morne/ Louw, Lorette. Considering the Interpretation and Implementation of Article 24 of the African Charter on Human and Peoples' Rights in Light of the SERAC Communicaition. African Human Rights Law Journal, Vol 3, pp. 167-187, (2003)

xvi. Wesson, Murray. Grootboom and Beyond: Assessing the socio-economic Jurisprudence of the South African Constitutional Court. South African Journal of Human Rights, Vol 20, No 284, (2004),

xvii. J Oloka - Onyango, Beyond the Rhetorics: Reinvigorating the Struggle for Economic and Social Rights in Africa Californian Western Internaional Law Journal, Volume 26 (1995) No 1

xviii. Mashood A Baderin, The African Commission on Human and Peoples Rights in Africa: Economic Social and Cultural Rights in Action

xix. The Role of the Courts in Protecting Economic Social and Cultural Rights

xx. Dejo Olowu An Integrative Rights-Based Approach to Human Development in Africa (Pretoria University Law Press 2009)

xxi. Evelyn Ankumah, The African Commission on Human and Peoples Rights : Practice and Procedures (The Hague Maritnis Nijhoff 1996)

xxii. N.J Udombana So far: the Local Regime Rules in the Jurisprudene of the African Commission on Human and Peoples Rights (January 2003) American Journal of International Law

xxiii. Christof Heyns, Civil and Political Rights in the African Charter

xxiv. Rahel Murray, Decision By the AfricanCommission on Charter on Human and Peoples Rights (1997) Vol 46 International Comparative Law Quarterly 412

xxv. Eva Reiter, The Use of Provisional Measures in the Context of the Various Human Rights Systems Makua MutuaThe African Human Rights System: A Critical Evaluation

xxvi. Richard Gittleman, The African Charter on Human and Peoples Rights: A legal Analysis 22 Va. Journal of International Law 667 (1982)

xxvii. Richard Gittleman The African Commission on Human and Peoples Rights: Prospects and Procedures; in Guide to International Human Rights Practice 153 (Hurst Haunum, ed; 1984)

xxviii. Cees Flinterman \& Evelyn Ankumah, The African Chater on Human and Peoples' Rights: in the giude to International Human Rights Practice 159 (Hurst Hannum, ed, 1992) 